Ана Јаковљевић Радуновић

Универзитет у Београду

Филолошки факултет

e-mail: anajakovljevic@yahoo.com

https://doi.org/10.18485/ai_san_o_gradu.2020.ch14

821.161.1.09-31

Оригинални научни рад

\title{
„ЛЕТО У БАДЕНУ” ИЛИ ХОДОЧАШЋЕ ПО \\ ГРАДОВИМА Ф. М. ДОСТОЈЕВСКОГ
}

У нашем раду анализиран је роман „Лето у Бадену“ Леонида Ципкина у коме се преплиће неколико реалности спојених у свести главног јунака. Неименовани приповедач седамдесетих година XX века путује из Москве у Лењинград и прати путовање кроз европске градове Ане Григорјевне и Фјодора Михајловича Достојевског из 1867. године. Кроз одвајање од свега свакодневног и познатог, он тежи да се приближи Истини о великом руском писцу. Наш задатак је да одредимо жанр Ципкиновог текста и да објаснимо због чега јунак романа позиционира Петербург као циљ свога ходочашћа.

Кључне речи: Достојевски, ходочашће, Леонид Ципкин, Карамзин, путопис, Холбајн Млађи.

Роман „Лето у Бадену“ доживео је светску славу када га је, како гласи општеприхваћена легенда, случајно у једној лондонској антикварници открила и прочитала чувена Сузан Зонтаг. Она је у листу Њујоркер (The New Yorker) објавила чланак о Леониду Ципкину искористивши податке које су јој доставили пишчев син и пријатељи, а роман је укључила у свој лични спи- 
сак десет најбољих романа двадесетог века (Мессерер 2010). У предговору за америчко издање романа 2001. године она је написала: „Овај роман, ја бих, без имало сумње, убројала међу најзначајнија, најистакнутија, најузвишенија и најоригиналнија достигнућа века препуног литературе и литерарности - у најширем смислу ове дефиниције“ (Зонтаг 2013: 5).

Леонид Ципкин, аутор романа „Лето у Бадену“, је белоруски Јеврејин рођен 1926. године у Минску. Чланови његове породице страдали су како за време рата и немачке окупације, тако и у време Стаљина и његове антисемитске послератне кампање. Радио је на Одељењу за онкологију Института за полиомијелитис и вирусне енцефалитисе. Када је Ципкинов син емигрирао у САД 1977. године, писац је, без обзира на титулу доктора медицинских наука и научна достигнућа, премештен на место приправника. Рад на делу „Лето у Бадену“ започео је 1977. и завршио га 1980. године. Делови романа штампани су први пут 13. марта 1982. у њујоршком недељнику Нова новина (Новая газета) на руском језику чији су уредници били Јевгениј Рубин и Сергеј Довлатов. Недељу дана касније, 20. марта 1982. године, Леонид Ципкин је умро.

Захваљујући напорима Сузан Зонтаг Ципкинов роман је постао сензација на Западу. Роман „Лето у Бадену“ донео је посмртно аутору светску славу и изазвао бурну полемику међу руским књижевним критичарима. Један од првих руских критичара који је високо оценио вредност и значај Ципкиновог дела био је Јосиф Бродски који је дело назвао „првокласним“ (Степанян 2004; Месcерер 2010).

У Русији дело је објављено као засебна публикација 2003. године и одмах је изазвало опречне реакције. Један број критичара, као и Сузан Зонтаг, сматра ро- 
ман „дубоком и трагичном“ књигом, ремек-делом „о љубави према Достојевском“ (Чупринина 2003; Степанов 2003; Туровская 2005). Други су писали да је то роман којем је стицајем повољних околности придат незаслужен значај (Кузнецова 2003; Эдельштейн 2004). Чињеница да је роман објавила издавачка кућа НЛО само је допринела повећању броја негативних рецензија (Калинин 2003). Посебно је за руске критичаре неприхватљиво то што је роман „открила“ Американка Сузан Зонтаг. Ана Кузњецова пише: „Замислите ситуацију краја двадесетог века у совјетологији и славистици: сви скандали су се слегли, сви дисиденти су прешли у мејнстрим, сва ремек-дела су откривена и рехабилитована. Откривање непознатог имена и непознатог ремек-дела постаје за слависту сан на граници утопије“ (Кузнецова 2003). На критику Кузњецове одговорио је Андреј Степанов. У својој рецензији он ју је прогласио за некомпетентну пошто је детаљно образложио да Сузан Зонтаг као један од највећих културолога, филозофа и теоретичара нашег времена и ауторка 30 књига, која је озбиљно утицала на савремену уметност, фотографију и експерименталну кинематографију тешко да је била забринута за кризу славистике, а још се мање бавила самопромоцијом (Степанов 2003). Михаил Еделштајн у тексту симптоматичног наслова „Руски роман, америчка монтажа“ тврди да је дело Ципкина само стилска вежба. Он се позива се на Меклину, која је раније писала да је само захваљујући маестралном преводу Анђеле и Роџера Киза на енглески, роман заживео новим животом (Меклина 2002) и тврди: „На нивоу где бели медведи и балалајке више не делују и нема стварног знања о руској култури, све би то требало да остави снажан утисак. Додајте 'тачном' садржају експериментални стил писања, употребу психоанализе, еротику 
оплемењену живописним метафорама и, на крају, добар превод - и биће врло лако објаснити успех извозне верзије руског романа“ (Эдельштейн 2004). Мејлахс се у свом тексту такође осврће на публицитет који је Ципкин добио у Америци и иронично примећује да „код њих Гогољи расту као печурке“, али сматра да уколико се остави по страни питање да ли је књига ремек-дело, у процесу читања читалац ће бити очаран текстом, који оставља нарочито јак утисак како се приближава крају „стварајући, између осталог, уверљив осећај да сви заиста живимо у историји, где се преплићу велико и мало, бесмртно и свакодневно“ (Мейлахс 2004).

Како је време одмицало, појавили су се и текстови у којима се Ципкиновом роману приступало на други начин. М. Туровска сматра дело великом „апотеозом књижевности“у време доминације визуелних садржаја. Она сматра да је стил романа где једна фраза може да заузме не само страницу, већ готово поглавље импресиван и да је Ципкину у том смислу најближи Бродски: „Обојица су забележили промену у концепту времена. Али ако се Бродски жели приближити тој 'монотонији', Ципкинов стил у себи садржи 'временску петљу': [...] прошлост и садашњост, различите прошлости се сударају и спајају унутар једне бездимензионалне реченице, једног граматичког трајања“ (Туровская 2005).

Критичари су имали противречна мишљења и о томе да ли је „Лето у Бадену“ биографски роман. Еделштајн истиче да ако је Ципкинова намера била да напише роман попут дела Ирвина Стона или Андреа Мориca, онда „његов компликован, експериментални начин писања само одвлачи читаоце од главне ствари - живота хероја - и неоправдано компликује перцепцију“ (Эдельштейн 2004). Маргарита Меклин је запазила да су читаоци на Амазону препоручивали да се прво про- 
чита биографија Достојевског, а онда Ципкинов роман - „иначе се можете изгубити у свим перипетијама путовања Достојевског и његове новопечене младе супруге“ (Меклина 2002). Туровска, међутим, у својој рецензији одаје почаст аутору „Лета у Бадену“ који можда није имао задатак да детаљно преноси догађаје из „Дневника“ Ане Григорјевне, али је неочекивано у свом тексту наслутио атмосферу и садржај треће свеске дневника која је остала необјављена све до 1993. године. Ова свеска није била расписана, пише Туровска, можда и због тога што је „потпунија и искренија када се [Ана Григорјевна] жали на коцкарске губитке, на сталну беду, на родбину свог супруга, замерке 'сиротој мајци' итд.- она је богатија за понижавајуће детаље“" (Туровская 2005).

У готово свим рецензијама на роман истиче се да је у основи односа јунака романа према Достојевском осећање љубави/мржње која „савија хронотоп романа“ (Rosen 2002; Сотникова 2003; Туровская 2005). У рецензији објављеној у Њујорк Тајмсу (The New York Times) Џонатан Розен бележи да је у овом „брилијантним роману“ Ципкин учинио Достојевском оно што је руски класик учинио са непредвидивим и застрашујућим Творцем - претворио га је у књижевни лик. За Розена „Лето у Бадену“ је истовремено акт литерарног омажа и освете. Лемхин ће две године после Розена писати о истом проблему, али за њега у роману постоји само „једноставна шема љубави и мржње према неправедном оцу и ривалство за његово наслеђе“ (Лемхин 2004).

За разлику од романа писаних у духу Достојевског какав је роман Џона Куција „Мајстор из Петрограда“, роман Ципкина не представља имитацију манира Достојевског. Роман Куција је код америчке критике изазвао недоумицу и негативне критике (Lawlan 1998: 136), али Еделштајн цинично запажа да је разлика између Ку- 
ција и Ципкина разлика између ствараоца и имитатора (Эдельштейн 2004). Антонио Мартинез Илан сматра да се ове две књиге могу описати као књиге „по Достојевском у другом смислу који је Карлински описао, у мери у којој се тичу психолошких процеса: у овом случају процеса писања. Оба писца стварају слику о себи засновану на романима Достојевског, где је писање (пре него живот) простор у коме могу да развију своју визију света и људске природе“ (Martínez Illán 2017). Књига Куција као и Ципкинова књига у основи представљају фикционализацију реалног писца. Куци је тај који је имитирао Достојевског, а Ципкин је тај који је покушао да створи нову форму. „Лето у Бадену“ је засновано на реалним датумима и догађајима из биографије Достојевског, али се не може сматрати документарним романом. Ципкин је посвећено проучавао Достојевског и зато је његов главни роман о њему. „Лето у Бадену“ није ни роман сан, као што га је у предговору назвала Сусан Зонтаг, нити је ово само роман тока свести, ово је пре свега роман о путовању и потрази. Док је радио на роману, Ципкин је небројено пута одлазио у Лењинград и сликао град, улице и зграде у оно доба дана и године када их је описао у својим делима Достојевски. Слике које су настале приликом тих посета северној престоници требало је да буду штампане уз роман. На крају их је писац поклонио Музеју Достојевског у Лењиграду. Роман „Лето у Бадену“ замишљен је као нека врста путописа по местима Достојевског, а овај додатак у виду фотогафија чини га много ближим жанру травелога и нашем времену него совјетској стварности и путописима шездесетих година.

Путописна књижевност настаје из потребе да се дође до нових знања: да се забележе географске особености другачијих, дотад невиђених предела или да се 
забележи слика места у једном историјском времену. Шачкова, систематизујући ставове руских теоретичара књижевности Гуминског, Михајлова, Шадрине, Стеценко, Маслове и других, изводи закључак о неколиким особеностима овог жанра: путописи обично имају лабаву структуру коју одликује недостатак строгих књижевних конвенција и жанровских канона, а структурирани заплет у текстовима овог жанра није обавезан, што не значи и одсуство композиционе и структуралне хармоније дела. Дајући предност излагању у првом лицу или у облику писама, путописна књижевност отвара пут субјективном виђењу света. Ауторов поглед на свет формира структуру текста. Путопис мора садржати документарне елементе, али путовање у одређеној мери и представља бег од стварности. Путописни текст садржи елементе других жанрова, било да се ради о дневнику, писму, аутобиографији или репортажи. Структура текста строго зависи од руте која представља његову основу (Шачкова 2008). Интересантно је промишљање савремених књижевних критичара попут Александра Чанцева који сматра да је травелог као модерна аналогија путописа веома важан жанр неограничене слободе: „...добар, јер је флексибилан, може се проширити до најудаљенијих граница, ultima thule. Или се могу имплозивно тражити могућности у себи, овладати дубинама, размишљати и урањати у себе“ те да се травелог може писати не излазећи из собе (Чанцев 2016). Роман „Лето у Бадену“ разматран је, као што смо видели, са различитих становишта, али руски критичари нису запазили оно што се нама чини неупитним: сви елементи путописног текста присутни су у делу Леонида Ципкина.

Руска модерна проза почела је са Карамзиновим путописом „Писма руског путника“ (1790), али у руској 
књижевности он је од XIX века до данас сматран периферним жанром, „не чак ни пасторком или рођаком са села, пре незваним гостом - Татарином - гастарбајтером“ (Чанцев 2016). Руска путовања на Запад почела су са Петром великим и његовим прагматичним путовањима у циљу усвајања нових знања, али су у деветнаестом веку путовали и племићи и интелигенција. Путовали су и велики руски писци деветнаестог века, али нису писали путописе. Гогољ је путовао по Европи и живео у Риму, ишао је на ходочашће у Палестину, али је на путовање по Русији морао да крене јунак „Мртвих душа“ Чичиков. Од свих руских писаца деветнаестог века у Европи је највише времена провео Тургењев, али ни он није писао путописе. Толстој своје утиске са путовања по Европи 1857. године, изложене у његовим бројним писмима, никада није нудио јавности. Руски писци који су писали путописе попут Гончарова („Фрегата Палада“) или Чехова („Острово Сахалин“), нису се у своје време прославили овом врстом текстова (Латынина 2016). За разлику од свих класика руске књижевности деветнаестог века, Достојевски је 1863. године, после свог путовања у Европу, написао циклус од осам есеја под називом „Зимске белешке о летњим утисцима“. Ово дело није посебно привлачило пажњу истраживача све до новијег времена, када су у њему открили нову форму есејистичке синтезе уметничког и филозофског материјала која је широко присутна у прози XX века. Акељкина и Шчеников истичу да филозофска активност аутора у „Зимским белешкама...“ готово сваку емпиријску чињеницу уздиже у ранг културног знака, менталног универзума и још: „Овде је писац први пут уметнички убедљиво и органски спровео синтезу различитих културних принципа, а јединствена ауторова позиција постала је облик те синтезе. [...] 
Истовремено, слика историјске стварности органски се комбинује са разумевањем њене вечне суштине, а духовна активност приповедача флексибилно балансира на ивици личног и универзалног („ја“ и „не-ја“, како је то рекао А. Ф. Лосев)“ (Акелькина, Щенников 2008).

Ципкинов роман „Лето у Бадену“ има двојаку експозицију. Радња почиње у зиму, крајем децембра, и све се догађа „сада“ док приповедач путује у Лењинград/ Петербург. Путовање Ање (Ане Григорјевне) и Феђе (Фјодора Михајловича), који су из Петербурга кренули у Дрезден, почиње средином априла 1867. године. Путујући кроз руску зиму аутобиографски јунак Ципкина чита о лету - јасно је да Ципкиново дело свој наслов дугује „Зимским забелешкама о летњим утисцима“. Достојевски на почетку свог путописа пише да нема ничег новог, непознатог, неиспричаног о Европи те да читаоци њу дупло боље познају него Русију. Писац набраја како је био у Берлину, Дрездену, Висбадену, Баден-Бадену, Келну, Паризу, Лондону, Луцерну, Женеви, Ђенови, Фиренци, у Милану, у Венецији, у Бечу а у појединим местима и два пута. Све ове европске градове аутор „Зимских бележака...“” обишао је за два и по месеца. Крајње иронично Достојевски пише како су се на западу нашли и мушки и женски примерци Чацког после бала код Фамусова, али и Репетилови, Скалозуби, Наталија Дмитријевна и њен муж па и грофица Хљестова тамо путује сваке године. Једино, тврди писац, Молчалина нема - он је остао „да служи отаџбини“. Господа која су се сукобљавала у Грибоједовљевој комедији, нашла су се на заједничком путовању зарад поклоњења вољеној Европи, њеној моди и наравима. Руског класика путовање Европом је подстакло да упореди европске и руске нарави, али и да напише понешто о руској књижевности, Белинском и Пушкину, о сло- 
боди („liberte“), о богатству и сиромаштву. Достојевски пише своја „размишљања из вагона“ и клопарање точкова задаје ритам у његовим белешкама за који писац тврди да изазива досаду: „Мени је било досадно у вагону па нека буде досадно и вама“. Ципкинов роман почиње реченицом „Воз је био дневни, али је била зима...", а клопарање точкова прерасло је ритмичку подлогу у тексту изражену цртама. Ципкин не пише биографију нити туристички водич по местима Достојевског иако елементи ових жанрова у тексту постоје. Он креће за омиљеним аутором и експериментише са формом пишући путопис који је и мало више од тога - ходочашће.

Ходочасничка литература као појава руске књижевности настајала је заједно са религијским феноменом који је у њеној основи. Главни подстицај за ауторе била је „тежња да се пренесе благодат светих места онима који нису имали прилике да до њих дођу“, али и жеља да се поново осети „веза са светим објектом и хармонија светих места“" (Сафатова 2012: 39). Посебно место међу ауторима који су писали ходочасничку литературу има Андреј Николајевич Муравјов (Гуминский 2011). У делу „Путовање на Света места 1830“ Муравјов посебно истиче да ходочашће у суштини јесте подвиг који подразумева савладавање просторних препрека, али да је још важнији од тога процес превладавања грешности и пут као начин духовног усавршавања (Сафатова 2012: 39).

Мотивација за путовање Ципкиновог јунака на почетку романа није одређена: „Зашто сам ја путовао у Петербург - не у Лењинград, него у Петербург, чијим је улицама ходао тај кратконоги, ниски (као уосталом и већина људи прошлог века) човек с лицем црквеног стражара или бившег војника?“ (25). Путовање обух-

5 Овде и даље сви цитати по Цыпкин, Леонид. Лето в Бадене. 
вата одлазак возом из Москве за Лењинград, долазак до Московске станице у северној престоници, ходање до стана Гилде Јаковљевне, у коме ће јунак вечерати и одморити се. Следећег дана, после дужег разговора са Гилдом, у предвечерје, он креће у шетњу до зграде у којој се налази Музеј Достојевског од кога га дели мање од пола сата хода чиме се завршава ово невелико путовање. Своје путовање у Лењинград писац претвара у „ход по душама својих јункака - Феђе и Ање, откривајући у себи невероватну моћ емпатије“ (Зонтаг 2013: 13). Вршећи ходочашће, човек путује у свето средиште, чиме потврђује свој идентитет припадника једне религијске традиције. Лајтмотив Ципкиновог романа који прати лик Феђе јесте успињање те није случајно што се на крају док умире Фјодору Михајловичу чини да се попео на највишу планину на свету (187), а млади Јеврејин има циљ да у Петербургу посети место са кога се велики руски писац коначно уздигао на небо.

У Ципкиновом роману пред јунаком се не појављују несавладиве препреке. Догађаји из седамдесетих година двадесетог века и они из 1867. испреплетани су у низу узрочно-последичних случајности. Аутобиографски херој Ципкина чита „Дневник“ Ане Достојевске и тиме остварује приопштавање Истини о великом писцу што је циљ сваког ходочашћа. За Ану Григорјевну одлазак из Петербурга је био и нужан и изнуђен: „Када су сели у вагон њој је изгледало да почиње нови живот“ (42). На неки начин и путовање Достојевских почело је из Москве. Брачни пар био је у посети сестри Фјодора Михајловича и писац је својој младој жени показивао град који је волео:

После свадбе, отпутовали су у Москву и одсели у гостио- 
ници Дисо, у малом апартману на трећем спрату, одакле су се видели звоници и куполе московских црквава под снегом, а доле - снегом засуте улице са траговима саоница, из гостионице су сваког дана саоницама, покривени топлим крзненим покривачем, ишли код његове сестре која је живела на Старој Басманој и успут би се заустављали поред Меншикове куле, а затим поред цркве Успења Богородице на Покровки, излазили су на неколико минута, да би обишли око цркве, - она је у Москви била први пут и он јој је све показивао онако како кућни домаћин показује своје ствари на које је поносан... (41)

Ана Григорјевна није била добро прихваћена у делу породице свога супруга која је живела у Москви. У последњем делу романа описујући последњи дан у животу Достојевског, аутор ће детаљно објаснити разлоге за бекство младе породице из Петербурга. Док Ана Григорјевна прима сестру Фјодора Михајлович, Веру Михајловну, која је из Москве дошла специјално да наговори брата да се одрекне свог дела наследства, она ће се присетити мучне улоге коју су рођаци њеног мужа имали у њиховом одласку из северне престонице. Паша, пасторак Фјодора Михајловича из првог брака, и Емилија Фјодоровна, жена његовог покојног брата, сматрали су да је Фјодор у обавези да им финансијски помаже. Писац је морао да заложи једини капут који је имао да би их се барем привремено ослободио. Захваљујући мајци Ане Григорјевне, која их је снабдела новцем, они су тада успели да напусте Петербург. У роману, Ципкин описује како млада жена одлазак у иностранство везује за помисао о помоћи Феђи и начин да сачува породицу (173).

Централни мотив који повезују разне слојеве текста јесте мотив успињања и са њим повезан мотив врха са еквивалентима као што су столица $(33 ; 34 ; 35 ; 143)$, 
планина (116), троугао (36; 116), ћошак (46; 100), златаста гомила новца (92) и кристални дворац (144). Када се Фјодор Михајлович нађе на врху, прати га „гомила која се смеје“ (92) чиме Ципкин као доминанту психолошког портрета истиче осећање унижености (Szabó 2017). Осећај понижености и повређености Ципкин везује за оба своја јунака и он је присутан у деловима романа у којима они бораве у западној Европи.

Од тренутка када Феђа и Ања долазе у Баден, Ципкин кроз паралелно виђење истих ствари показује колико се њих двоје разликују. Фјодор Михајлович пре свега у немачкој бањи види место и прилику за коцкање:

Кроз зеленило башти, које покривају обронке планине, он је видео бело двоспратно здање са готским кровом, на чијим су прозорима чак и дању били навучене тешке плишане завесе, на плафону у облаку дуванског дима били су укључени кристални лустери, који су осветљавали сале обавијене у зелено (70).

Ана Григорјевна види исти пејзаж, али пред њом је бања са свечано и лепо одевеним људима и она замишља како ће овде пријатно провести време са својим мужем:

Стижемо, - рекао јој је, - она је видела кроз прозор вагона високу планину покривену зеленилом, кроз које су се назирале беле куће црвених кровова и међу њима готски звоници цркава, а изнад свега тога небо са лаким облацима који плове по њему - управо тако је она замишљала тај град, али су морали да се спреме за излазак и да спакују ствари [...] Ана Григорјевна се приљубила уз прозор и загледала у зграду станице и фигуре људи, који су ходали по платформи, ... - био је то жив, прави Баден, и она је већ видела себе како с мужем шета главном улицом 
Бадена Lichtentaler Alle, - о којој је толико слушала, међу сређеним и дотераним гостима, пошто пресвуче своју црну чипкану мантилију и обуче раскошну хаљину са карнерима, јер је Феђа сада морао да има среће (70-71).

Супружници су сваког дана ишли у баденску галерију, „као што у Кисловодску иду на извор да попију воду или да се виде или да стоје и посматрају посетиоце“ (27), а онда су ишли да ручају. Са описом ручкова почињу се назирати стварни обриси породичне драме Достојевских: сваки пут ресторани су на исти начин „живописно наднесени над Елбом“, али је сваки пут сума плаћена за храну детаљно наведена. После краткотрајног периода среће „живот Достојевских у Бадену почео је да личи на ноћ без сна“ (113). Феђа губи и троши оскудна средства којима располажу. Мучи Ању љубомором и мучи се сам покушавајући да у све што се догађа унесе барем мало логике. Повремено тоне у размишљања о цифрама, попут Раскољникова или Пушкиновог Хермана са којима дели страст према коцки, и израчунава број корака од куће до коцкарнице. Коцка је страст Достојевског: кад добија, он у гомили новца види врх који осваја, али и кад губи он трага за тим недостижним врхом-троуглом. Он на сваки начин покушава да се попне, уздигне, дође до врха:

...сунце је залазило и осветљавало планину са Старим и Новим замком који су су се на њој видели и Феђа се зауставио да ужива у пејзажу, и замолио ју је да се заустави и погледа ту слику зато што је то био веома редак моменат када су истовремено оба замка била осветљена и врх планине покривен зеленилом, - још минут и замкови ће утонути у сенку и нестаће сунчани троугао, али је Ана Григорјевна наставила да иде даље као да није било тог осветљеног троугла који су формирале назубљене куле замкова и врх планине... (116). 
Ана Григорјевна у том троуглу не види метафизички знак, она је обузета земаљским проблемима, али га без одушевљења прати по Lichtentaler Alle jep „није хтела да иде том алејом у својој хаљини за по кући, скоро јединој која јој је остала пошто су заложили ствари“ (116). Ако се Ања пење по каменим степеницама замка, њени разлози нису метафизичке природе - она бежи од мужа који је изгубио док се коцкао па је дошао да тражи од ње и последњу пару, којом би требало платити газдарици да их не истерају из стана (104). Тема успињања прати и сазнање да је Ана Григорјевна трудна: кад је привуку градски призори Бадена и тајанствена лепота његових замкова на планини она оклева да се пење „зато што се плашила да се не спотакне и падне и тако изгуби будућу Соњечку или Мишу“ (75).

Одлазак из Бадена који се у једном тренутку Ани Григорјевној учинио немогућим (139), донео је супружницима олакшање а прелазак преко Рајне као да је означио нову етапу у њиховим животима. Стигли су у Базел. Чим су се сместили Достојевски су, као и у сваком другом месту, изашли да разгледају град, углавном саборни храм и локални музеј. Једина ствар вредна пажње у Базелу сем назива хотела у коме су одсели била је слика Холбајна Млађег, коју Ана Григорјевна назива „Смрт Исуса Христа“, иако је њен прави назив био „Мртви Христ“ (142). То је тренутак када за Фјодора Михајловича почиње успињање. Најпре је оно физичко: он се без оклевања пење на столицу да би боље разгледао платно необичног формата. За разлику од сличног инцидента у Дрездену када је физичким успињањем писац желео да превазиће сопствену немоћ и осећање понижености (33-36), приближавање Холбајновој слици или пењање ка „Мртвом Христу“ Цип- 
кин назива „савршено јасним детаљем - првим кристалом, који је изашао из презасићеног раствора, - остало, засад скривено густом маглом, требало је да дође само од себе - с новом снагом се загледао у слику - она је на неколико тренутака избледела, и на њеном месту су се појавила позната лица..." Леонид Ципкин показује како је откриће слике Холбајна Млађег преобразило Достојевског. Интересантно да је овај доктор, патолог како га називају критичари, успео да у свом роману из 1980. године открије оно за шта ће истраживачима књижевности бити потребно скоро још две деценије - открио је сижејно-композициони и идејно-филозофски центар романа „Идиот“.

Важно је приметити да је Ципкинов путопис овде остварио још једну тачку додира са историјом руске путописне књижевности:

... руски културни човек XIX века упознавао са познатом сликом Холбајна Млађег по правилу посредно: на основу њеног описа и интерпретације у Карамзиновим 'Писмима руског путника'. Руски културни човек XX века упознавао се са истом сликом посредством романа Достојевског „Идиот“ и коментара уз њега, који су се углавном позивали на Карамзинов текст. Тако је Холбајнова слика већ скоро два века саставни део фонда руске културе. У том својству она је симбол смрти Христа без васкрсења, симбол победе „закона природе“ над највећом људском драгоценошћу, коју је смрт победила и поразила (Касаткина 2006).

Татјана Касаткина је приметила да се Карамзин, као ни Ана Григорјевна која је у „Дневнику“ пренела своје утиске о слици, нису пели на столицу. Промена позиције посматрача, променила је и смисао слике. Достојевски се попео на столицу. Двадесет година пре 
свих историчара књижевности Леонид Ципкин је схватио да је тренутак успињања на столицу у базелском музеју, тренутак коперниканског обрта у стваралаштву Достојевског. Успињање Достојевског на столицу завршило се брзом женином реакцијом и он је попут месечара напустио своју осматрачницу, али је остао на висини: „он се налазио на врху планине, на оном врху који му се раније чинио недостижним, и одатле му се отварао поглед скоро на целу планету са њеним градовима, рекама, сеоцима, океанима и црквама [....] можда се он сада налазио у кристалном дворцу који је тако упорно тражио док је покушавао да се попне на врх“ (144). Потрага је за Достојевског била завршена - врх је био освојен и одговор пронађен.

Достојевски умире у Петербургу, међу својима, пошто се опростио са својом породицом и под будним оком Ане Григорјевне. У Петербург је вођен својом опсесијом дошао и Ципкин тражећи међу каменим фасадама по бескрајним булеварима трагове Достојевског. На крају Ципкиновог путовања појављује се лик Јеврејке Гилде, сиромашне старице, која је преживела лењинградску блокаду, која је способна да воли своје комшије и опрашта непријатељима, па чак и жени која јој је одузела мужа. Андреј Степанов сматра да се овде ради о свесној Ципкиновој конструкцији о нечему што је Достојевски сањао али никада није успео да оствари у животу, а то је истинска хришћанска љубав (Степанов 2003) и, парадоксално, ту свеобухватну, свепраштајућу љубав осећа једна Јеврејка. Петербург је у руској књижевности и руској историји пространство смрти - отуда и помињање Лењинградске блокаде. У „Лету у Бадену“ Петербург је Лазарева гробница Достојевског чији се улаз отвара снагом вере и љубави. У „Злочину и казни“ он је камена гробница за Раскољни- 
кова. Причу о Лазаревом васкрсењу читају блудница Соња и убица Раскољников и, ако је за Соњу јасно да у њеном случају трули тело, али не и душа, остаје нејасно како се ова прича односи на Раскољникова - убицу који се није покајао. Татјана Касаткина пише да по схватању Достојевског у сваком од нас, иза камена, у гробници, трули Христов пријатељ. Човек иза камена остаје жив, не умире до краја, јер је пријатељ Христов и слика бесмртног Христа. Човека из гробнице спашавају други људи, јер су они ти који вером и љубављу померају камен иако је Христ тај који га подиже из мртвих (Касаткина 2003). Једно од суштинских питања које Ципкин поставља себи јесте зашто је он, као и бројни књижевни историчари и критичари Јевреји опседнут писцем који је мрзео Јевреје. Ако се подсетимо да духовно прочишћење јесте суштина ходочашћа, онда је јасно да и Ципкинов јунак пролази кроз процес усавршавања. Ципкина и Ану Григорјевну повезује неколико ствари: и једно и друго пишу о великом писцу, а да ни он ни она нису писци по професији, и њихов однос према писцу одређен је пламеном великодушношћу супружанске љубави, која је безусловна и безгранична, али која не гарантује срећу у случају Ане Григорјевне, али и свепраштајућом љубави јеврејског лекара Ципкина према руском писцу Достојевском.

\section{Извори и литература}

Акелькина Е.А, Щенников Г.К. «Зимние заметки о летних впечатлениях». Щенников Г. К, и ТИХОМИРОВ, Б. Н. Достоевский: Сочинения, письма, документы: Словарь-справочник. СПб.: Издательство «Пушкинский Дом», 2008. 209-211. Штампано.

Гуминский, Виктор Мирославович. «Русская паломническая 
литература между Востоком и Западом». Литературоведческий журнал 42 (2017): 168-244. Веб. 14.04. 2020.

Зонтаг, Сюзан. «Любить Достоевского». Леонид Цыпкин. Лето в Бадене. Москва: НЛО, 2013. 5-19. Штампано.

Калинин, Глеб. «Леонид Цыпкин. Лето в Бадене». Эксперимент. Ру. Архив, 2.10. 2003. Веб. 14.04. 2020.

Касаткина, Татьяна Александровна. «После знакомства с подлинником. Картина Ганса Гольбейна Младшего Христос в могиле в структуре романа Ф. М. Достоевского Идиот». Новый Мир, 2 (2006). Веб. 14.04. 2020.

Касаткина, Татьяна Александровна. «Воскрешение Лазаря: опыт экзегетического прочтения романа Ф. М. Достоевского 'Преступление и наказание'». Вопросы литературы, 1 (2003) 176-208. Веб. 14.04. 2020.

Качалкина, Юлия. «Прогулки с Достоевским». НГ ехлибрис, 10.07. 2003. Веб. 14.04. 2020.

Кузнецова Анна. «'Шедевр' патологоанатома». Водяные знаки, 24: 1.09. 2003. Веб. 14.04. 2020.

Латынина, Алла. «Одинокие голоса проводников. Писатели о травелогах». Лиterraтура 88: 2016. Веб. 14.04. 2020.

Лемхин, М. «Доктор Цыпкин и доктор Гинденбург». Новый мир 6 (2004). Веб. 14.04. 2020.

Меклина Маргарита. «Какой прошляпали шедевр!» Критическая Масса 1 (2002). Веб. 14.04. 2020.

Мейлахс А. «Место на литературном Олимпе. (Леонид Цыпкин. Лето в Бадене)». Октябрь 8 (2004). Веб. 14.04. 2020.

Мессерер, Азарий. «Прерванная лекция». Чайка/ Seagull 16 (171) (16. 08. 2010). Веб. 14.04. 2020.

Szabó, Tünde. «Биография и орнаментализм в постмодернистском романе о Достоевском (Лето в Бадене Л. Цыпкина)». Acta Universitatis Lodziensis. Folia Litteraria Rossica 10 (2017): 67-80. Веб. 14.04. 2020.

Сафатова, Евгения Юрьевна. «Традиции паломнической литературы в творчестве А. Н. Муравьева». Вестник Томского государственного университета 356 (2012). Веб. 14.04. 2020.

Степанов, Андрей. «Читайте Цыпкина!» Русский Журнал. Круг чтения (3.09. 2003). Веб. 14.04. 2020. 
Степанян, Карен. «Леонид Цыпкин. Лето в Бадене». Знамя 6, (2004). Веб. 14.04. 2020.

Туровская Майя. «'Лето в Бадене', или большое приключение литературы». Зарубежные записки 2 (2005). Веб. 14.04. 2020.

Цыпкин, Леонид. Лето в Бадене. Москва: НЛО, 2013. Штампано.

Чанцев, Александр. «Одинокие голоса проводников. Писатели о травелогах». Лиterraтура 88 (2016). Веб. 14.04. 2020.

Чупринина, Юнна. «170 страниц про любовь. «Последний русский роман XX века» впервые напечатан по-русски». Итоги 19/361 (2003). Веб. 14.04. 2020.

Шачкова, В. А. ««Путешествие» как жанр художественной литературы: вопросы теории». Вестник Нижегородского университета им. Н.И. Лобачевского, 3 (2008): 277-281. Веб. 14.04. 2020.

Эдельштейн, Михаил. «Русский роман, американская сборка». Знамя 6 (2004). Веб. 14.04. 2020.

Martínez Illán, Antonio. "Two fictional journeys in the life of Dostoevsky: Typskin's Summer in Baden-Baden and Coetzee's The Master of Petersburg». Church, Communication and Culture 2-3 (2017): 308-321. Веб. 14.04. 2020.

Lawlan, Rachel. "The Master of Petersburg: Confession and Double Thoughts in Coetzee and Dostoevsky». ARIEL: A Review of International English Literature 29:2 (1998): 131-157. Веб. 14.04. 2020.

Rosen, Jonathan. "Crimes and Punishments (Summer in BadenBaden by Leonid Tsypkin)». The New York Times Section 7, Page 10 (3.03.2002). Веб. 14.04. 2020. 
Ana Jakovljević Radunović

\section{«SUMMER IN BADEN» OR PILGRIMAGE TO CITIES OF F. M. DOSTOYEVSKY}

\section{Summary}

The journey of Typskin's hero is conceived as a travelogue, but it is a kind of pilgrimage to the cities of Dostoevsky. LeonidTypskin shows that moving through space for his hero is less significant than the intellectual plunge into Dostoevsky's biographyand novels. Changing cities is moving along a horizontal plane, but also climbing along the spiritual vertical, and realistic movement is a material projection of a spiritual journey. Typskin'sautobigraphic hero and Dostoyevsky have the same task of overcoming feelings of humiliation and climbing to the top. Through separation from everything everyday and known, the hero discovers the Truth about the great Russian writer and his creation.Typskinin his novel «Summer in Baden-Baden» continues the tradition of writing travel books with which modern Russian prose began.

Key Words: Dostoevsky, pilgrimage, Leonid Tsipkin, Karamzin, travelogue, Holbein the Younger. 